\section{Penerapan Uang Elektronik Dalam Peningkatan Kepatuhan Pembayaran Pajak Bagi Wajib Pajak Di Indonesia}

\author{
Regi Handono
}

Universitas Narotama, regi.handono@gmail.com

\begin{abstract}
Tax payment compliance has always been a polemic in any country in the world, including in Indonesia. Indonesia applies a taxation system in the form of self-assessment in which taxpayers have full authority in carrying out their tax obligations. On the one hand, this principle is very good for the tax authorities or the Directorate General of Taxes (DGT), because it reduces their administrative costs. With taxpayers calculating, paying, and reporting their own tax obligations, DGT is on the passive side because it is only a matter of waiting for tax deposits and reports. On the otherhand this also creates new problems. DGT very much depends on the honesty, willingness and level of understanding of taxpayers of their respective tax rules and obligations. The main problem with this principle is the honesty stage. Humans basically will always try with the least possible sacrifice and will try to get the maximum result or benefit. Meanwhile, tax, however its form, is still an expense that must be borne by the taxpayer. This is what causes taxpayers, to always arise reluctance to pay taxes which in the next stage is trying to find ways to reduce tax payments as small as possible. Meanwhile, the state always expects the income from the tax payments of its citizens to ensure the survival and the implementation of development as a whole. For this reason, a breakthrough is needed so that these differences in interests can reach a good common ground for all parties.
\end{abstract}

Keywords: Tax; Electronic Money; Fiscus.

\begin{abstract}
Abstrak
Kepatuhan pembayaran pajak selalu menjadi polemik di negara manapun di dunia, termasuk di Indonesia. Indonesia menerapkan sistem perpajakan dalam bentuk self assessment dimana wajib pajak memiliki kewenangan penuh dalam menjalankan kewajiban perpajakannya. Di satu sisi, prinsip ini sangat baik bagi otoritas pajak atau Direktorat Jenderal Pajak (DJP), karena mengurangi biaya administrasi. Dengan wajib pajak menghitung, membayar, dan melaporkan sendiri kewajiban perpajakannya, DJP berada di sisi pasif karena tinggal menunggu setoran dan laporan pajak. Namun di sisi lain hal ini juga menimbulkan masalah baru. DJP sangat bergantung pada kejujuran, kemauan dan tingkat pemahaman Wajib Pajak terhadap peraturan dan kewajiban perpajakan masing-masing. Masalah utama dengan prinsip ini adalah tahap kejujuran. Manusia pada dasarnya akan selalu berusaha dengan pengorbanan yang seminimal mungkin dan akan berusaha untuk mendapatkan hasil atau manfaat yang maksimal. Sedangkan pajak, bagaimanapun bentuknya, tetap menjadi beban yang harus ditanggung oleh wajib pajak. Hal inilah yang menyebabkan para wajib pajak selalu timbul keengganan untuk membayar pajak yang pada tahap selanjutnya berusaha mencari cara untuk mengurangi pembayaran pajak sekecil mungkin. Sementara itu, negara selalu mengharapkan pendapatan
\end{abstract}

Halaman | 90

\section{Jurnal}

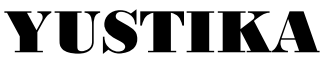

Media Hukum dan Keadilan Fakultas Hukum Universitas Surabaya Vol. 23 No. 02, Desember 2020 P-ISSN: 1410-7724, E-ISSN: 2655-7479 
Jurnal Yustika

Vol. 23 No. 02, Des 2020

Halaman | 91

Penerapan Uang

Elektronik Dalam

Peningkatan

Kepatuhan

Pembayaran Pajak Bagi Wajib Pajak Di Indonesia

Regi Handono dari pembayaran pajak warganya untuk menjamin kelangsungan hidup dan pelaksanaan pembangunan secara keseluruhan. Untuk itu diperlukan terobosan agar perbedaan kepentingan tersebut dapat mencapai titik temu yang baik bagi semua pihak.

Kata Kunci: Pajak; Uang Elektronik; Keuangan.

\section{Pendahuluan}

Anggaran Pendapatan dan Belanja Negara, atau yang sering disingkat menjadi APBN, adalah suatu daftar perincian yang telah disusun secara terstruktur dan sistematis yang memuat penerimaan dan pengeluaran negara selama 1 (satu) tahun anggaran, di mana tahun anggaran selalu menggunakan periode 1 Januari - 31 Desember. APBN sendiri terdiri atas 3 (tiga) bagian utama, yaitu pendapatan negara, belanja negara, serta pembiayaan negara. Pendapatan negara selalu bersumber dari 2 (dua) hal, yaitu penerimaan pajak dan penerimaan negara bukan pajak (sering disingkat menjadi PNBP). Penerimaan pajak memiliki kontribusi sebanyak $80 \%$ lebih terhadap total penerimaan dalam APBN. Hal tersebut menunjukkan pentingnya pajak sebagai sumber penerimaan negara dalam membiayai pembangunan di negara ini, baik pembangunan infrastruktur maupun pembangunan non infrastruktur, seperti sumber daya manusia.

Tabel 1.

Postur RAPBN tahun 2020 (Rp Triliun)

\begin{tabular}{|c|l|c|c|}
\hline \multicolumn{2}{|c|}{ KETERANGAN } & RAPBN & APBN \\
\cline { 3 - 4 } \multicolumn{2}{|l|}{} & $\mathbf{2 0 2 0}$ & $\mathbf{2 0 2 0}$ \\
\hline I & PENDAPATAN NEGARA & $\mathbf{2 . 2 2 1 , 5}$ & $\mathbf{2 . 2 3 3 , 2}$ \\
\hline & PENERIMAAN PAJAK & $1.861,8$ & $1.865,7$ \\
\hline & PENERIMAAN NEGARA BUKAN PAJAK & 359,3 & 367,0 \\
\hline II & BELANJA NEGARA & 0,5 & 0,5 \\
\hline & BELANJA PEMERINTAH PUSAT & $\mathbf{2 . 5 2 8 , 8}$ & $\mathbf{2 . 5 4 0 , 4}$ \\
\hline & TRANSFER KE DAERAH DAN DANA DESA & $1.670,0$ & $1.683,5$ \\
\hline III & KESEIMBANGAN PRIMER & 858,8 & 856,9 \\
\hline IV & DEFISIT ANGGARAN & $\mathbf{( 1 2 , 0 )}$ & $\mathbf{( 1 2 , 0 )}$ \\
\hline & \% terhadap PDB & $\mathbf{( 3 0 7 , 2 )}$ & $\mathbf{( 3 0 7 , 2 )}$ \\
\hline V & PEMBIAYAAN ANGGARAN & $\mathbf{3 0 7}, \mathbf{2}$ & 1,76 \\
\hline
\end{tabular}

Sumber: Kementerian Keuangan (diakses dari www.kemenkeu.go.id)

APBN, dalam dunia akuntansi, sering dianalogikan sebagai laporan budgeting dalam suatu perusahaan, di mana realisasi dari laporan budgeting tersebut akan menjadi laporan laba rugi (profit and loss). Penerimaan negara dianalogikan sebagai pendapatan usaha, dan belanja negara 
dianalogikan sebagai beban (expenses) yang harus dikeluarkan oleh organisasi tersebut agar kelangsungan usahanya tetap terjamin.

Jurnal Yustika

Salah satu prinsip akuntansi yang sering digunakan dalam suatu organisasi adalah prinsip going concern atau keberlangsungan usaha. Prinsip ini mengasumsikan bahwa suatu organisasi didirikan dengan tujuan untuk berjalan secara terus menerus, atau bukan dalam jangka pendek, yang berarti akan menjadi suatu anomaly apabila seseorang mendirikan suatu organisasi dengan tujuan hanya untuk berlangsung selama beberapa saat saja. Prinsip tersebut kurang lebih sama dengan yang dianut oleh pemerintah.

Pemerintah sebagai salah satu organ dalam negara ini memiliki hak dan kewajiban untuk menjamin keberlangsungan hidup negara ini untuk selama-lamanya. Keberlangsungan hidup tersebut tidak hanya semata-mata hidup saja, namun juga termasuk harus berkembang. Suatu negara agar dapat berkembang membutuhkan biaya yang tidaklah sedikit mengingat tingkat inflasi yang terjadi terus menerus. Apabila penerimaan negara tidak mencukupi untuk menutupi biaya dan belanja negara, maka pemerintah dapat menutupinya melalui utang dengan berbagai macam bentuknya, namun utang ini juga bukan merupakan suatu solusi mutlak karena solusi yang paling ideal adalah suatu organisasi harus dapat bertahan hidup berdasarkan perputaran uangnya sendiri.

Hal ini berarti kondisi yang ideal dari suatu negara adalah penerimaan negaranya haruslah lebih besar atau setidak-tidaknya dapat menutupi biaya dan belanja negara. Apabila negara menutupi defisit biaya dan belanja negaranya dari pinjaman, maka solusi tersebut hanyalah solusi sementara karena suatu negara yang yang melakukan peminjaman atau utang tetap harus memikirkan jalan keluar untuk membayar atau mengembalikan utang tersebut. Selain itu utang tidak dapat dihindari apabila pengembangan hendak dilakukan. Merupakan suatu hal yang wajar ketika suatu organisasi atau negara melakukan peminjaman atau utang untuk memicu terjadinya pengembangan dari organisasi atau negara tersebut, karena apabila menunggu perputaran uang yang cukup untuk melakukan suatu pengembangan, maka niscaya hal tersebut akan sulit untuk dilakukan.

Indonesia sendiri di tahun 2020 ini digolongkan sebagai negara berkembang, meskipun di awal tahun yang sama sempat dikelompokkan menjadi negara maju oleh Office of The US Trade Representative (USTR) atau Kantor Perwakilan Perdagangan Amerika Serikat. Banyak yang menilai bahwa penggolongan Indonesia sebagai negara maju tersebut lebih banyak disebabkan oleh faktor politik daripada keadaan yang sesungguhnya, karena tidak atau belum adanya definisi dan batasan yang jelas mengenai negara maju dan negara berkembang. World Trade Organization (WTO) sendiri sampai dengan hari ini tidak memberikan definisi yang jelas mengenai negara berkembang. Suatu negara dapat memutuskan secara sepihak apakah ia termasuk dalam negara maju atau negara berkembang, namun tetap harus mendapatkan persetujuan dari seluruh negara anggota WTO.

Meskipun Indonesia digolongkan sebagai negara berkembang, namun pada prinsipnya Indonesia masih memiliki berbagai macam kendala terutama dalam hal pengumpulan dana pajak sebagai sumber utama penerimaan negara. Dalam setiap perkembangan peradaban, baik ekonomi, sosial, maupun budaya, penyesuaian aturan perpajakan selalu menjadi salah satu aspek yang tertinggal dibandingkan aspek lainnya (Denny Vissaro, 2020). Apalagi di tahun 2020 yang merupakan tahun yang cukup berat tidak hanya bagi Indonesia saja namun bagi berbagai negara lainnya yang menghadapi tekanan perlemahan ekonomi yang cukup besar, berbagai bentuk kebijakan fiskal dan upaya peningkatan penerimaan pajak dilakukan oleh
Vol. 23 No. 02, Des 2020

Halaman | 92

Penerapan Uang

Elektronik Dalam

Peningkatan

Kepatuhan

Pembayaran Pajak

Bagi Wajib Pajak

DI Indonesia

Regi Handono 
Jurnal Yustika

Vol. 23 No. 02, Des 2020

Halaman | 93

Penerapan Uang

Elektronik Dalam

Peningkatan

Kepatuhan

Pembayaran Pajak Bagi Wajib Pajak Di Indonesia

Regi Handono
Kementerian Keuangan dan Direktorat Jenderal Pajak (DJP). Salah satu yang sedang gencar dilakukan oleh pemerintah saat ini adalah perluasan basis pajak. Pemerintah merasa bahwa basis pembayar pajak (wajib pajak) selama ini masih belum mencerminkan angka seluruhnya. Banyak wajib pajak, terutama yang berada di usia produktif dan telah memiliki penghasilan, tidak menghitung, melaporkan, dan membayar pajaknya. Pemerintah sendiri, melalui DJP sering beranggapan bahwa apabila terjadi penurunan ekonomi sehingga berakibat pada menurunnya penerimaan negara dalam bentuk pajak, maka dibutuhkan upaya lain seperti pemerataan beban pajak melalui berbagai macam strategi maupun kebijakan yang tepat sasaran (Brondolo, 2009). Selain sebagai upaya dari pemerintah guna menjaga stabilitas penerimaan pajaknya, kebijakan ini juga merupakan salah satu upaya dalam membagi beban pajak secara lebih merata sesuai dengan kemampuan pembayaran pajak oleh wajib pajak (OECD, 2018). Selain itu, dari hasil ekstensifikasi yang dilakukan oleh DJP dan dilaporkan dalam Data Laporan Kinerja (Lakin) menunjukkan bahwa wajib pajak baru pada suatu tahun belum atau tidak membayar pajak pada tahun berikutnya. Contohnya adalah, dari 570.127 wajib pajak orang pribadi yang tidak tergolong sebagai karyawan yang terdaftar pada database DJP di tahun 2016, hanya 285.206 wajib pajak yang memenuhi kewajiban pembayaran pajaknya pada tahun yang sama dan hanya 115.092 wajib pajak yang memenuhi kewajiban pembayaran pajaknya di tahun berikutnya. Hal yang sama pun terjadi pada 2018 di mana dari 554.998 wajib pajak orang pribadi yang tidak termasuk dalam kriteria penerima kerja (karyawan) yang terdaftar pada 2017, hanya 152.971 wajib pajak yang memenuhi kewajiban pembayaran pajaknya di tahun 2018.

Penyebab lain sulitnya menghimpun dana pajak dari masyarakat adalah pola penerimaan pajak yang tidak seimbang (Kristiaji, 2018). Kontribusi penerimaan pajak selama beberapa tahun terakhir ini didominasi oleh Pajak Pertambahan Nilai (PPN) dan Pajak Penghasilan (PPh) Badan sebanyak 50\% hingga 60\%. Hal ini mengindikasikan bahwa kontribusi PPh Orang Pribadi masih jauh dari potensi maksimal sesungguhnya. Selain itu, dengan pola penerimaan seperti saat ini mengakibatkan penerimaan pajak memiliki risiko menurun terutama ketika menghadapi perlemahan ekonomi. Padahal PPh Orang Pribadi semestinya dapat menjadi penopang penerimaan pajak ketika adanya gejolak ekonomi. Sebagai informasi, pada tahun 2019, penerimaan PPh yang berasal dari karyawan (PPh Pasal 21) berada di kisaran 11,2\%. Kemudian, PPh Pasal 25 Orang Pribadi yang berasal dari masyarakat berpenghasilan tinggi justru hanya memberikan kontribusi sebesar 0,8\%. Last but not least, salah satu penyebab rendahnya penerimaan negara dari pajak adalah kecilnya partisipasi jumlah wajib pajak. Per 2019, jumlah wajib pajak yang terdaftar baru mencapai 31,4\% dari total generasi usia produktif atau generasi pekerja. Oleh karena itu, modernisasi di bidang pajak melalui optimalisasi teknologi terutama teknologi digital merupakan hal yang perlu dilakukan, dibarengi dengan perubahan paradigma wajib pajak dalam memandang pajak itu sendiri. Optimalisasi digital ini salah satunya dapat diwujudkan dalam bentuk penggunaan uang elektronik sebagai sarana penghimpun dana perpajakan dari wajib pajak. Direktorat Jenderal Pajak mengharapkan uang elektronik ini dapat mempermudah wajib pajak dalam 
memenuhi kewajiban pembayaran pajaknya sekaligus memudahkan fiscus dalam menghimpun dana perpajakan secara adil dan merata.

Melihat sulitnya penghimpunan dana dari masyarakat untuk penerimaan negara dalam bentuk pajak, maka timbul pertanyaan, (1) Apakah penggunaan uang elektronik dapat mempermudah penghimpunan dana untuk pembayaran pajak?, (2) Apakah potensi hambatan yang muncul dari penerapan uang elektronik tersebut?

\section{Pembahasan}

\subsection{Peranan Uang Elektronik dalam Meningkatkan Kepatuhan Pembayaran Pajak}

Secara umum pajak dapat didefinisikan sebagai suatu hal yang wajib bagi setiap orang ketika bertempat tinggal di suatu negara, di mana pembayaran pajak tersebut merupakan bentuk pengabdian serta kontribusi langsung dari warga negara dan setiap anggota masyarakat untuk secara bersama-sama membiayai berbagai keperluan negara dalam pembangunan nasional. Ciri khas dari pajak adalah warga negara tidak dapat mengharapkan imbalan secara langsung. Pajak ini secara tidak langsung memberikan sisi yang positif kepada warga negara karena menggunakan uang pribadi dari setiap orang, namun dalam pelaksanaan dan pengelolaannya diserahkan kepada pemerintah pusat dan dikembalikan secara merata kepada seluruh warga negaranya. Pelaksanaan pemenuhan hak dan kewajiban perpajakan sendiri diatur dalam undang - undang perpajakan yang berlaku demi kesejahteraan bangsa dan negara. Dengan semakin adanya keterbukaan informasi, perkembangan teknologi, dan berkembangnya suatu kondisi usaha dan bisnis baik itu ditingkat nasional maupun internasional, maka penghasilan yang diterima oleh setiap wajib pajak, baik itu wajib pajak orang pribadi maupun badan dalam negeri juga akan mengalami peningkatan. Wajib pajak orang pribadi dan badan (perusahaan) merupakan salah satu jenis subjek pajak dalam negeri di mana wajib pajak tersebut merupakan salah satu pemberi kontribusi bagi penerimaan negara dari sektor pajak yaitu pajak penghasilan orang pribadi dan pajak penghasilan badan dengan berbagai macam bentuk dan jenisnya.

Menurut Undang - Undang Nomor 28 tahun 2007 tentang Ketentuan Umum dan Tata Cara Perpajakan Pasal 1 angka 3, wajib pajak dapat dibedakan menjadi beberapa jenis, antara lain wajib pajak orang pribadi dan badan, yang mencakup pembayar pajak, pemotong pajak, dan pemungut pajak, di mana mereka memiliki hak dan kewajiban perpajakan sesuai dengan ketentuan peraturan perundang-undangan perpajakan yang berlaku atau memiliki kewajiban subjektif dan kewajiban objektif serta wajib mendaftarkan diri untuk memperoleh Nomor Pokok Wajib Pajak (NPWP). Sedangkan yang menjadi objek pajak penghasilan menurut Undang - Undang Pajak Penghasilan Nomor 42 tahun 2009 adalah penghasilan, yaitu setiap tambahan kemampuan ekonomis yang diterima atau diperoleh wajib pajak, baik yang berasal dari Indonesia maupun dari luar Indonesia, yang dapat dipakai untuk konsumsi atau untuk menambah kekayaan wajib pajak badan yang bersangkutan, dengan nama dan dalam bentuk apa pun.

Sebelum dimulai penjelasan lebih dalam mengenai peranan uang elektronik, harus dipahami terlebih dahulu mengenai definisi uang elektronik yang sesungguhnya agar diperoleh pemahaman yang sama. Menurut Peraturan Bank Indonesia Nomor 11/12/PBI/2009 tanggal 13 April 2009 tentang Uang Elektronik (Electronic Money), uang 
Jurnal Yustika

Vol. 23 No. 02, Des 2020

Halaman | 95

Penerapan Uang

Elektronik Dalam

Peningkatan

Kepatuhan

Pembayaran Pajak

Bagi Wajib Pajak

Di Indonesia

Regi Handono elektronik adalah alat pembayaran dalam bentuk elektronik di mana nilai uangnya disimpan dalam media elektronik tertentu. Pengguna atau pemilik dana harus menyetorkan sejumlah dana terlebih dahulu kepada penerbit uang elektronik dan disimpan dalam media elektronik sebelum dapat menggunakannya untuk bertransaksi. Ketika uang elektronik tersebut digunakan, nilai uang di media elektronik tersebut secara otomatis akan terpotong sebesar nilai transaksi, dan dalam suatu saat tertentu sewaktuwaktu dapat ditambahkan kembali nilainya oleh pengguna atau pemilik dana. Menurut Surat Edaran Bank Indonesia No.11/11/DASP tanggal 13 April 2009 perihal Uang Elektronik (Electronic Money), suatu uang dapat didefinisikan sebagai uang elektronik apabila memenuhi unsur-unsur sebagai berikut, yaitu: (1) diterbitkan berdasarkan nilai uang yang telah disetor terlebih dahulu kepada penerbit; (2) nilai uang tersebut disimpan secara elektronik dalam suatu media penyimpanan seperti server atau chip; (3) nilai uang elektronik yang dikelola oleh penerbit bukan merupakan simpanan sebagaimana yang diatur dalam undang-undang mengenai perbankan.

Peranan uang elektronik ini diyakini akan semakin meningkat terutama apabila dikaitkan dengan isu pemanasan global dan pandemic Covid-19 yang melanda Indonesia sejak akhir tahun 2019, karena dengan penggunaan uang elektronik akan mengurangi penggunaan kertas (paperless) dan mengurangi sarana atau media interaksi yang memudahkan penyebaran virus atau penyakit. Perlu dipahami bahwa uang kertas meskipun disebut uang kertas namun bahan dasarnya sendiri bukan dari kertas melainkan dari kapas. Kapas dipilih sebagai bahan dasar pembuatan uang kertas karena sifatnya yang lebih tahan air dan tidak mudah sobek ketika dilipat dibandingkan bahan kertas. Namun bahan kapas ini memiliki efek negatif terhadap lingkungan. Seperti diketahui bahwa sampah kapas tergolong dalam jenis sampah organik yang efeknya terhadap lingkungan sama dengan sampah anorganik. Menurut analisa yang dilakukan oleh Bank Dunia di tahun 2018 terhadap 15 kota di bagian tengah dan barat Indonesia menunjukkan bahwa sampah kota terdiri atas jenis yang bervariasi, yang $44 \%$ di antaranya adalah sampah organik (Dwi Hadya Jayani, 2014). Sampah kapas ini harus dikelola dengan menggunakan landfill system, di mana dengan sistem ini sampah akan ditimbun di dalam tanah sehingga menghasilkan gas metana yang dapat digunakan sebagai tenaga listrik. Namun sayangnya, landfill system ini membutuhkan lahan yang cukup luas untuk tempat pembuangan akhir, sehingga mempengaruhi kesehatan dan lingkungan bagi warga sekitarnya. Selain itu, dengan menggunakan landfill system, tanah yang semula bersih dari sampah menjadi tanah yang bercampur dengan sampah dan limbah, baik organik maupun anorganik, sehingga akan mempengaruhi kualitas air tanah akibat limbah sampah yang meresap ke dalam tanah dan akan menyebabkan berkumpulnya berbagai macam penyakit di sekitar wilayah tersebut (Iwan Budisantoso, 2011).

Uang elektronik sendiri direncanakan agar dirancang di dalam satu media penyimpanan seperti kartu, misal KTP elektronik (E-KTP) di mana kartu tersebut memuat seluruh identitas pemilik dana termasuk identitas perpajakannya. Apabila diringkas ke dalam satu media seperti itu akan memudahkan masyarakat sebagai wajib pajak karena tidak perlu membawa media, seperti kartu, yang terlalu banyak. Apabila diperhatikan secara seksama, dengan dijalankannya uang elektronik secara tidak langsung akan memicu digunakannya transaksi elektronik juga dalam sistem perdagangan di Indonesia. Selain itu, masing-masing orang harus memiliki semacam alat elektronik yang ke 
depannya mungkin dapat diintegrasikan dengan telepon genggam (handphone), di mana di dalam handphone tersebut telah tertanam suatu aplikasi agar dapat saling bertransaksi dengan orang lain. Dengan diterapkannya transaksi elektronik ini maka data dapat otomatis terekam sehingga ketika wajib pajak melakukan suatu transaksi, fiscus pun juga dapat mendeteksi apakah transaksi tersebut merupakan transaksi jual beli atau sekedar pemberian cuma - cuma. Apabila transaksi elektronik yang dijalankan oleh wajib pajak tersebut merupakan transaksi jual beli maka di sisi pembeli akan menjadi transaksi pengeluaran dana dan di sisi penjual akan menjadi transaksi penerimaan dana. Di transaksi elektronik penerimaan dana itulah dapat ditelusuri lebih lanjut apakah merupakan transaksi yang terutang pajak atau tidak, dan apabila terutang pajak maka dapat dilakukan debet otomatis guna pembayaran pajak terutangnya.

Dapat dibayangkan apabila skema uang elektronik ini dapat dijalankan dengan baik akan memicu terjadinya peningkatan kepatuhan pembayaran pajak karena penghimpunan dana masyarakat dari pembayaran pajak tidak lagi mengandalkan kejujuran wajib pajak namun secara sistem dapat dilakukan secara otomatis. Selain meningkatkan kepatuhan pembayaran pajak, dapat juga meningkatkan ketepatan dan kecepatan pembayaran pajak. Oleh karena pembayaran pajak dilakukan secara otomatis oleh sistem menyebabkan pemerintah dapat mengurangi risiko kesalahan perhitungan, pembayaran, maupun pelaporan yang dilakukan oleh wajib pajak sehingga cost of administration yang harus dikeluarkan oleh pemerintah guna penarikan pajak dapat ditekan seminim mungkin.

Transaksi dengan uang elektronik juga akan menyebabkan berkurangnya potensi dispute atau kebingungan terhadap aturan perpajakan. DJP dapat menekan grey area yang selama ini sering dimanfaatkan oleh wajib pajak dalam menekan pembayaran pajaknya. Bagaimanapun juga, secara sadar atau tidak sadar, pemerintah sering kali menimbulkan suatu kondisi atau keadaan yang memungkinkan terjadinya dispute seperti itu, yang membuat timbulnya perselisihan pendapat antara wajib pajak dengan fiscus sehingga harus diselesaikan hingga ke pengadilan pajak. Penyelesaian hingga ke pengadilan pajak ini menimbulkan biaya dan penggunaan waktu yang tidak sedikit. Selain itu sering kali fiscus dihadapkan pada situasi di mana tidak semua masyarakat, yang seharusnya memiliki kewajiban untuk menghitung, melapor, dan membayar pajak, mengerti dan paham aturan maupun tata caranya. Apabila uang elektronik ini dijalankan secara baik maka segala effort, baik itu usaha, tenaga, dan waktu, yang dikeluarkan untuk mengatasi dispute perpajakan ini dapat dialihkan ke hal-hal lain yang membutuhkan perhatian lebih.

\subsection{Potensi Hambatan Yang Muncul dari Penerapan Uang Elektronik}

Pepatah China lama, yaitu Yin dan Yang mengatakan bahwa segala hal di dunia ini selalu memiliki dua sisi yang saling bertolak belakang, begitu juga dengan uang elektronik. Seperti yang telah dijabarkan di atas bahwa penerapan uang elektronik sebenarnya memiliki banyak sekali manfaat, namun di sisi lain juga memiliki potensi hambatan yang bisa terjadi sewaktu-waktu. Hambatan utama yang harus siap dihadapi adalah terkait dengan cyber crime. Penerapan uang elektronik ini membutuhkan kecerdasan buatan agar dapat berjalan dengan baik. Cyber crime sendiri dapat didefinisikan sebagai kejahatan di bidang komputer, yang secara sederhana dapat diartikan sebagai menggunakan komputer secara illegal (Anda Hamzah, 1989). Cyber crime juga dapat diterjemahkan sebagai kejahatan yang menggunakan teknologi komputer sebagai sarana utamanya. (Girasa, 2002). Cyber 
Jurnal Yustika

Vol. 23 No. 02, Des 2020

Halaman | 97

Penerapan Uang

Elektronik Dalam

Peningkatan

Kepatuhan

Pembayaran Pajak

Bagi Wajib Pajak

Di Indonesia

Regi Handono crime hanya dapat dilakukan dengan menggunakan teknologi cyber dan hanya dapat terjadi di dunia cyber (Tavani, 2000). Kejahatan di dunia maya ini sudah banyak terjadi terutama ketika penggunaan internet semakin meningkat di beberapa tahun belakangan ini. Dimulai dengan tingkat yang paling sederhana seperti penyebaran virus, malware, dan sebagainya, hingga pencurian data. Padahal pada saat itu transaksi elektronik belum banyak terjadi, sehingga dapat dibayangkan apabila konsep uang elektronik ini dijalankan, Pemerintah melalui Badan Siber dan Sandi Negara harus berupaya secara terus menerus menjamin keamanan data warga negara Indonesia. Akan menjadi suatu hal yang bertolak belakang apabila DJP mampu meningkatkan kepatuhan pembayaran pajak wajib pajak melalui penerapan uang elektronik ini, namun di sisi lain Badan Siber dan Sandi Negara menghabiskan dana yang tidak sedikit untuk mengamankan data warga negara Indonesia. Perlu diketahui pula bahwa Badan Siber dan Sandi Negara dengan hacker sering kali dianalogikan seperti penyakit dan obat. Ketika muncul suatu penyakit, para ilmuwan akan berlomba-lomba untuk mencari obat dari penyakit tersebut. Begitu obat tersebut ditemukan, akan muncul penyakit lain atau pengembangan dari penyakit itu yang membuat para ilmuwan harus berupaya tanpa henti mencari penangkalnya.

Hal lain yang berpotensi menghambat penerapan uang elektronik sebagai sarana peningkatan kepatuhan pajak adalah terkait dengan kerahasiaan data nasabah. Seperti yang telah diketahui bahwa lalu lintas transaksi terutama yang melibatkan uang, sering disebut dengan sistem pembayaran, menggunakan bank sebagai salah satu pihaknya. Sistem pembayaran adalah sistem yang terkait dengan perpindahan sejumlah nilai uang dari satu pihak kepada pihak yang lain. Bank sebagai lembaga keuangan yang terpercaya (trust financial institution), merupakan lembaga tempat penyimpanan dan pengelolaan uang nasabah. Salah satu bentuk pelayanan dan apresiasi bank kepada nasabahnya adalah mengelola dan menggunakan uang nasabah dengan sebaik mungkin dan berkewajiban menjaga semua data informasi terkait dengan nasabahnya. Mengingat pentingnya data dan informasi nasabah beserta simpanannya, maka dalam Undang - Undang Nomor 10 tahun 1998 tentang Perbankan, yang selanjutnya disebut sebagai Undang - Undang Perbankan, diatur secara jelas pada Bab VII mengenai Rahasia Bank, di mana dalam Pasal 40 Undang Undang Perbankan menyatakan bahwa bank wajib merahasiakan keterangan tentang nasabah penyimpan dan simpanannya. Sejalan dengan ketentuan tentang kerahasiaan bank, Otoritas Jasa Keuangan (OJK) juga telah mengeluarkan Surat Edaran Nomor 14/SEOJK.07/2014 mengenai Kerahasiaan dan Keamanan Data dan/ atau Informasi Pribadi Konsumen. Surat Edaran ini diterbitkan sehubungan dengan telah diberlakukannya Peraturan Otoritas Jasa Keuangan Nomor 1/POJK.07/2013 mengenai Perlindungan Konsumen Sektor Jasa Keuangan. Pada prinsipnya, Surat Edaran OJK dan POJK tersebut mengatur mengenai para Pelaku Usaha Jasa Keuangan (PUJK), termasuk bank, yang memiliki kewajiban untuk melindungi data dan atau informasi pribadi konsumen dan melarang, dengan cara apa pun, untuk memberikan data dan atau informasi pribadi konsumen tersebut kepada pihak ketiga. Namun demikian, tetap ada beberapa kondisi yang memungkinkan atau mewajibkan bank untuk membuka data nasabah. Justru bank bahkan bisa dikenakan sanksi jika tidak memberikan data nasabah tersebut ketika diperlukan, salah satunya adalah adanya permintaan pembukaan data dari otoritas pajak, dalam hal ini DJP. 


\section{Kesimpulan}

Berdasarkan penjelasan di atas, maka dapat ditarik kesimpulan sebagai berikut, yaitu:

1. Banyak wajib pajak yang merasa bahwa pengenaan pajak yang dibebankan kepadanya tidak adil karena dirasa terlalu berat, tidak sebanding dengan wajib pajak yang lainnya. Sebagian besar wajib pajak sering merasa atau berasumsi seperti itu. Hal inilah yang membuat banyak wajib pajak tersebut sering merasa keberatan untuk membayar pajak yang seharusnya memang menjadi tanggung jawabnya. Di lain pihak pemerintah melalui DJP terus mengupayakan peningkatan pembayaran pajak dengan meningkatkan basis pajak, menurunkan tarif pajak, dan lain sebagainya, padahal wajib pajak memiliki kemauan untuk membayar pajak apabila pengenaan pajak ini dapat dilakukan secara merata. Apabila pembayaran pajak dikaitkan dengan transaksi elektronik, secara otomatis wajib pajak mengetahui bahwa antara wajib pajak yang satu dengan yang lain telah dibebani pajak yang sama sehingga niscaya kepatuhan pembayaran pajak juga akan meningkat.

2. Digitalisasi di semua aspek kehidupan akan dan sedang terjadi, termasuk digitalisasi di bidang perpajakan. Dalam waktu dekat, big data akan digunakan sebagai salah satu acuan dalam mengawasi wajib pajak secara real time. Di sisi lain, DJP pasti juga akan secara terus menerus berupaya meningkatkan kemudahan dan kesederhanaan sistem pajak, misal dalam hal pembayaran pajak yang akan semakin mudah. Hal ini sesuai dengan keinginan Menteri Keuangan Republik Indonesia saat ini, Sri Mulyani, yang menginginkan pembayaran pajak semudah transaksi online melalui berbagai macam platform. Pemanfaatan teknologi termasuk di bidang perpajakan membuat DJP semakin mudah, cepat, tepat, dan akurat dalam memperoleh data, sehingga dalam hal ini peranan analis data akan semakin ditingkatkan. Hal itu berarti wajib pajak memiliki celah yang semakin sedikit dalam upayanya mencari cara untuk tidak membayar pajak.

\section{Daftar Referensi}

Buku:

Abdul Wahid. (2011). Kejahatan Mayantara (Cyber Crime). Jakarta: Refika Aditama.

Adami Chazawi. (2005). Tindak Pidana Mengenai Kesopanan. Bandung: Rajagrafindo Persada.

Brondolo. (2009). Strategi Perluasan Basis Pajak di Tengah Perluasan Ekonomi. Jakarta: DDTC.

Darussalam, Danny Septriadi, B.Bawono Kristiaji, \& Denny Vissaro. (2019). Era Baru Hubungan Otoritas Pajak dengan Wajib Pajak. Jakarta: DDTC.

Deris Setiawan. (2005). Sistem Keamanan Komputer. Jakarta: PT Elex Media Komputindo.

Girasa. (2002). Cybercrime Pemahaman dan Upaya Pencegahan Kejahatan Berteknologi. Yogyakarta: Citra Aditya Bakti.

Hamzah, Andi. (1989). Aspek-Aspek Pidana di Bidang Komputer. Jakarta: Sinar Grafika.

Iwan Budisantoso. (2011). Sukses Mengolah Sampah Organik menjadi Pupuk Organik. Semarang: Pustaka Baru Press.

Maskun. (2012). Kejahatan Siber (Cyber Crime) Suatu Pengantar. Bandung: Prenada.

Sujarwo, Tristanti, Widyaningsih, \& Dwi Hadya Jayani. (2014). Pengelolaan Sampah Organik dan Anorganik. Yogyakarta: Universitas Negeri Yogyakarta. 
Jurnal Yustika

Vol. 23 No. 02, Des 2020

Halaman | 99

Penerapan Uang

Elektronik Dalam

Peningkatan

Kepatuhan

Pembayaran Pajak

Bagi Wajib Pajak

Di Indonesia

Regi Handono
Peraturan Perundang-Undangan:

Undang - Undang Nomor 36 tahun 2008 tentang Pajak Penghasilan

Undang - Undang Nomor 42 tahun 2009 tentang Pajak Pertambahan Nilai Barang dan Jasa dan Pajak Penjualan atas Barang Mewah

Undang - Undang Nomor 28 tahun 2007 tentang Ketentuan Umum dan Tata Cara Perpajakan

Undang - Undang Nomor 10 tahun 1998 tentang Perbankan

Peraturan Otoritas Jasa Keuangan Nomor 1/POJK.07/2013 mengenai Perlindungan Konsumen Sektor Jasa Keuangan

Surat Edaran Nomor 14/SEOJK.07/2014 mengenai Kerahasiaan dan Keamanan Data dan/ atau Informasi Pribadi Konsumen

Surat Edaran Bank Indonesia No.11/11/DASP tanggal 13 April 2009 perihal Uang Elektronik (Electronic Money)

Peraturan Bank Indonesia Nomor 11/12/PBI/2009 tanggal 13 April 2009 tentang Uang Elektronik (Electronic Money) 